\title{
A Marcha das Margaridas: resistências e permanências
}

Berenice Gomes da Silva

Curso: Mestrado em Sociologia

Data da defesa: 6 de junho de 2008

Orientadora: Prof ${ }^{a}$ Dr $^{a}$ Berenice Alves de Melo Bento

\section{Resumo}

A pesquisa aborda a trajetória das mulheres trabalhadoras rurais em torno da Marcha das Margaridas (MM) - uma estratégia de mobilização realizada por um conjunto de movimentos de mulheres e que em 2007 teve como lema: Contra a fome, a pobreza e a violência sexista. Realizada em Brasília (DF) a cada três anos, a Marcha das Margaridas conta com a presença de mulheres oriundas de todas as regiões brasileiras. É retratada neste estudo como uma ação coletiva realizada por mulheres trabalhadoras rurais que constituem uma identidade política, a partir de problemas comuns ao meio rural brasileiro. O objetivo da pesquisa é identificar como o gênero é constituído na Marcha das Margaridas e como os desdobramentos resultantes desse conceito são identificados nas categorias poder e identidade. A análise é permeada pela diferença localizada nas tensões permanentes tanto na relação com os próprios movimentos de mulheres trabalhadoras rurais que integram a MM quanto com as demais redes de movimentos com as quais a Marcha se relaciona. $\mathrm{O}$ referencial teórico-metodológico é fundamentado nas contribuições de Scott (1992), Lauretis (1994), Descarries (2003), Foucault (1979, 1988), Hall (1999), Melucci (1989, 1990) e Sherer-Warrer (2005). A partir da apreensão do conceito de gênero como produto e processo 
das relações sociais, os resultados indicaram que o gênero influenciou as práticas sociais das mulheres trabalhadoras rurais. O poder, visto como algo difuso e em constante disputa, assim como o gênero, localiza-se dentro e fora das estruturas sociais e é exercitado na MM mediante alianças e tensões permanentes. A unidade diz respeito à identidade política respaldada em uma pauta comum, porém, as diferenças acabam sendo reveladas pela diversidade e pluralidade das mulheres presentes na MM: agricultoras familiares, assentadas, quebradeiras de coco, pescadoras, quilombolas, mulheres do campo, das águas e das florestas que formam um mosaico identitário. Apesar dessa pluralidade e diversidade, a afirmação da identidade política de mulheres trabalhadoras rurais na MM reforça a idéia de um sujeito mulher universal ancorado por uma essência feminina. Por outro lado, afirmar essa identidade configura-se em uma estratégia importante para evidenciar as mulheres trabalhadoras rurais como sujeitos de direitos historicamente negados e que impedem o reconhecimento de sua própria existência como seres humanos. Suas práticas sociais, permeadas pelas relações de poder, revelam que a atuação em rede proporciona articulações locais e globais. Ao questionar o Estado e os seus próprios movimentos, a MM rompe com estruturas sociais hierarquizadas e hegemonicamente masculinas e pauta um novo modelo de desenvolvimento do País. Assim, ao evidenciar que as desigualdades de gênero estão presentes em todas as relações sociais, a investigação acerca da MM aponta para novas possibilidades de apreensão das teorias e estudos feministas.

Palavras-chave: mulheres; gênero; poder. 